\title{
THE EFFECT OF COOPERATIVE INTEGRATED READING AND COMPOSITION LEARNING MODELS AND STUDENT TEAM ACHIEVEMENT DIVISIONS ON LEARNING RESULTS AND COLLABORATION OF STUDENTS IN NURSING THEORY MATERIAL
}

\author{
Yosefina Nelista $^{1 *}$, Pembronia Nona Fembi ${ }^{2}$, Teresia Elfi ${ }^{3}$ \\ 1,2,3 The Nusa Nipa University Campus, Maumere \\ E-mail*: nelistayosefina@gmail.com
}

\begin{abstract}
Introduction: An understanding of nursing theory requires critical thinking skills. Therefore effective learning methods are needed to improve student understanding. One method of learning that can overcome this is the Cooperative Integrated Reading and Composition (CIRC) method and the Student Team Achievement Divisions (STAD) method. The aim was to analyze the effectiveness of CIRC learning models and STAD Method on student learning outcomes and collaboration. Methods: This study used a quasi-experimental method consisting of two experimental groups with the study design was a post-test design with two comparison treatments. The population in this study were all semester two undergraduate students nursing as many as 30 people divided into two groups - the sampling technique conducted by total sampling. We analyzed the data using the Mann Whitney test with $\alpha \leq 0.05$. Results: The mean rank of learning outcomes in the CIRC method was 19.43, and the STAD method was 11.57. The p-value was 0.007 (<0.05), which means that there was a significant difference between learning outcomes in the CIRC group and the STAD group. The mean rank value for student collaboration on the CIRC method was 15.50, and the STAD method was 15.50. The p-value was 1,000 (>0.05), which means there was no significant difference between the collaboration in the CIRC group and the STAD group. Conclussions: There were significant differences between learning outcomes in the CIRC group and the STAD Group. However, there was no significant difference between collaboration in both groups.
\end{abstract}

Keywords: collaboration; cooperative integrated reading and composition; learning results; student team achievement divisions

\section{INTRODUCTION}

Nursing theory is an attempt to describe and explain various phenomena in nursing. Nursing theory plays a role in differentiating nursing from other disciplines and aims to describe, explain, estimate, and control the results of care or nursing services performed (Alligood, 2017). There are three ways to approach in the development and formation of nursing theories, namely borrowing methods from other relevant disciplines, analyzing the situation of nursing practice to look for concepts related to nursing practice and creating a conceptual framework that enables the development of the nursing theory (Smith, et al 2014)

An understanding of nursing theory requires high and critical thinking skills so that the approach needed can answer the learning objectives. Therefore, active learning methods are necessary to improve students' understanding of nursing theory.

The Faculty of Nursing at the University of Nusa Nipa, notably the Nursing Undergraduate Program, still uses the classic learning method, which using the lecture method for nursing theory courses. Students are not actively involved in finding problems and learning about nursing theory. This causes many students to have low mastery of nursing theory subjects. This can be seen from the little evaluation scores each semester in nursing theory courses, with an average rating below 60 . Based on the results of interviews with 10 students, they said that nursing theory is complicated to understand and remember.

Learning methods such as lectures will only develop cognitive aspects of students, while affective elements are also expected in learning outcomes. The expected effective aspect is the ability of interpersonal 
relationships with classmates that can be achieved through group learning methods. To meet the learning needs of current undergraduate nursing students, and respond to mandates for bettered prepared graduates, nurse educators must restructure curricula and teaching strategies. One strategy to increased attention and active learning is the flipped classroom learning. Flipped teaching expected students to have completed pre-class material, such as assigned reading, instructor-prepared lecture video(s), and PowerPoint slides. In-class activities included the review of challenging topics, modified team-based learning (TBL) sessions, and an individual assessment. Teambased learning also appears to promote team participation and improved knowledge (Haidet, 2014)

One of the appropriate learning methods to overcome the above issues is the CIRC type of cooperative learning method. CIRC is a comprehensive learning model by reading and writing that involves student cooperation in a group where the success of the group depends on the success of each individual in the group (Slavin, 2010).

The CIRC learning models can be categorized into integrated learning. The development of CIRC resulted from an analysis of traditional problems in reading, writing, and language arts. In CIRC learning, each student is responsible for group assignments. Each group member put forward ideas to understand a concept and complete a task, so that formed understanding and learning experiences. In the CIRC learning model, students are placed in small heterogeneous groups. Each learning model has its characteristics (Andang, 2017).

The use of CIRC learning models can be directed to improve student understanding. Therefore, students are required to be active and participate more critically, imaginatively, and creatively (Rosalina et al., 2016). In addition to the CIRC method, other cooperative learning methods can improve student understanding, namely the Student Team Achievement Divisions method.
The STAD method is a learning technique that consists of several small groups with different abilities to complete learning tasks and cooperate (Huda, 2014). The main idea of STAD is to motivate students to be able to support one another and assist one another in mastering the abilities taught by the teacher. If students want their team to get a team award, they must help their teammates learn the material (Slavin, 2010).

Based on the results of literature studies and observations of existing phenomena, we are interested in conducting this research and hope that the Cooperative Integrated Reading and Composition learning model and Student Team Achievement Divisions can improve learning outcomes and collaboration among students.

\section{METHODS}

We used a quasi-experimental method consisting of two experimental groups, namely group A with The CIRC learning method and group $\mathrm{B}$, with the STAD learning method. The design used in the study was a post-test design with two comparison treatments.

The population in this study were all semester two students of the Nursing Undergraduate Program as many as 30 people and were divided into two groups (1 group received the CIRC learning method, and 1 group received the STAD learning method).

The sampling technique in this study was total sampling. The sample size was not calculated based on any formula because all members of the population being study samples (total sampling).

The independent variables in this study were the Cooperative Integrated Reading and Composition learning model and Student Teams Achievement Divisions, and the dependent variables were student learning outcomes and collaboration. The research instrument used to view student collaboration is an observation sheet containing aspects of teamwork or cooperation, leadership, tolerance, and communication. 
The instruments used to apply both methods were the teaching plan, task descriptions (individuals and groups), attendance lists, and flash disks containing learning material. Learning outcomes were assessed through individual and group assignments collected at a particular time with the assignment grading rubric. The assignment rubric is directly evaluated by the lecturer Individual tasks were carried out independently while group assignments were carried out collaboratively with group members consisted of five students. Individual and group assignment rubrics were made differently to facilitate more detailed assessments; the group assignments had aspects of teamwork/cooperation, leadership, tolerance, and communication that were not found in individual tasks. The data scale was the ratio. The range of grades was 0 to 100 . Quiz scores, different assignments were added up to group assignments, then averages and final exams, and then entered into statistical tests (data normality test and Whitney man test). Data were analyzed using the Mann Whitney test. The hypothesis is a short answer from research (Sugiyono, 2016). The hypothesis in this study uses an alternative hypothesis. This study has been approved by ethical test in our institution.

This research was approved by the ethics commission for Health Research, Faculty of Health Sciences, Nusa Nipa University No. 57/EC/FIKES/NN/VI/2019.

\section{RESULTS}

Table 1 Distribution of respondents based on age and sex $(n=30)$

\begin{tabular}{lcl}
\hline & Respondents characteristics \\
\hline Characteristics & $\mathrm{f}$ & Percentages (\%) \\
\hline 1. Age & & \\
a. 19 years old & 8 & 26.7 \\
b. 20 years old & 12 & 40.0 \\
c. 21 years old & 10 & 33.3 \\
\hline 2. Sex & & \\
a. Male & 13 & 43.3 \\
b. Female & 17 & 56.7 \\
\hline
\end{tabular}

Table 2 Student Learning Outcomes and Collaboration with the CIRC and STAD Method

$(\mathrm{n}$ $=30$ )

\begin{tabular}{lllll}
\hline \multicolumn{2}{c}{ Learning method } & & \\
\hline & CIRC $(\mathrm{n}=15)$ & & \multicolumn{2}{l}{ STAD $(\mathrm{n}=15)$} \\
\hline Learning outcome & $\mathrm{f}$ & $\%$ & $\mathrm{f}$ & $\%$ \\
a. Fair & & & & \\
b. Good & 0 & 0 & 4 & 26.7 \\
c. Excellence & 7 & 46.7 & 9 & 60.0 \\
\hline
\end{tabular}

\section{Student collaboration}

\begin{tabular}{lllll} 
a. Great teamwork & 10 & 66.7 & 10 & 66.7 \\
b. Super teamwork & 5 & 33.3 & 5 & 33.3 \\
\hline Mean Rank (Learning outcome) & 19.43 & & 11.57 & \\
\hline Mean Rank (Collaboration) & 15.50 & & 15.50 & \\
\hline P value (Learning outcome) & $\mathrm{p}=0.007$ & & & \\
\hline P value (Collaboration) & $\mathrm{p}=1.000$ & & & \\
\hline
\end{tabular}


Based on the characteristics of the respondents in Table 1 above, it can be concluded that the age of students with a mostly 20 years old as many as 12 people $(40 \%)$ and only a few that aged 19 years old as many as eight people $(26.7 \%)$. More than half of the respondents were female as many as 17 people $(56.7 \%)$.

Data normality test results for student learning outcomes and collaboration using the Shapiro-Wilk test obtained data with abnormal distribution ( $\mathrm{p}=0.000)$, so the statistical analysis used was the Mann Whitney test.

Student learning outcomes and collaboration in Table 2 showed that learning outcomes using the CIRC method were more students had excellent results as many as eight people (53.3\%), and those using the STAD method were more students had good results as many as nine people $(60 \%)$. The results of student collaboration for the CIRC method and the STAD were in a high category (great team), which each consisted of 10 people (66.7\%).

Based on the mean rank of learning outcomes in Table 2 above, the value obtained in the CIRC method was 19.43 , and the STAD method was 11.57. This showed that the learning outcomes in the CIRC method were better than the learning outcomes in the STAD method. From this output, it can be seen that the significance was 0.007 . Because p-value $<0.05$, then Ho was rejected, Ha was accepted so it can be concluded that there was a significant difference between learning outcomes in the CIRC group and the STAD group.

The mean rank value for student collaboration in Table 2 was 15.50. This showed that the cooperation in the CIRC and STAD methods was the same. From this output, it can be seen that the significance was 1.000 . Because $\mathrm{p}$ value> 0.05, then Ho was accepted, Ha was processed so that it can be concluded that there was no significant difference between the collaboration in the CIRC group and the STAD group.

\section{DISCUSSIONS}

Student learning outcomes using the CIRC method were more in the excellent category, and those using the STAD method were more in the good category. Based on the mean value, it showed that learning outcomes in the CIRC method were better than the STAD method. This shows that there are significant differences between learning outcomes in the CIRC group and the STAD group.

This study is in line with research conducted by Epina et al. (2018) about the Effect of the Use of Cooperative Learning Models of CIRC Type on Improving Understanding of Students' Concepts. This study showed that the use of the CIRC learning model had reached $94 \%$ and was classified very well, and there was a significant influence of the use of the CIRC model on improving the ability to understand concepts or student learning outcomes.

Similar research was also carried out by Puspitasari (2019) on the Effectiveness of Implementing Integrated CIRC Against Understanding Student Concepts. The results showed that the application of the CIRC model to conceptual understanding had very significant effects compared to using conventional learning methods. This can be seen from the considerable value of 0.001 $<0.05$. This was also supported by the results of student observations, which showed that students had more enthusiasm and more curiosity.

CIRC learning is an activity that encourages students to work together in teams with members of different levels of ability (Afendi, 2017). The same thing was said by Sutiyem (2019) Cooperative Integrated Reading and Composition (CIRC) Model requires students to work in pairs in teams that are assigned to participate in a series of specific activities. Learning that uses CIRC aims to improve the ability of students to understand reading or lessons as well as to enhance student learning outcomes while the STAD model is a learning technique that consists of some small groups with abilities different to complete 
learning tasks and working together (Huda, 2014).

Differences in learning outcomes in nursing theory material in the two groups of respondents can occur due to weaknesses in the learning method. The mean rank of learning outcomes using the CIRC method was higher than the mean rank of learning outcomes using the STAD method so that a significant difference between learning outcomes in the CIRC group and the STAD Group.

Learning outcomes of the CIRC method was higher than the STAD method due to the CIRC method combining the ability to write and read cooperatively (groups). Students read material taught from various sources and then write it in written form done cooperatively. This can improve the ability of students to learn and receive feedback from reading activities that have been carried out.

This is in line with the opinion of Heriawan (2012), which stated that the Cooperative learning model Integrated Reading and Composition (CIRC) is an integrated learning model combining capabilities write and read so hopefully can train students to collaborate and provide feedback and have the freedom to express themselves. The same statement was expressed by Jatmiko et al. (2013), who stated that the CIRC method is a special teaching program designed to improve student performance in reading and writing. So students can put out ideas to understand a concept and complete tasks, thus forming an understanding and long learning experience.

Student collaboration results on the CIRC and STAD methods had the same mean range value of 15.50 . This shows that the collaboration on the CIRC and STAD methods is the same. Stages in the cooperative learning model type STAD and CIRC can improve the attitude of cooperation between students in the context of learning activities in groups (teamwork). In this step, students are required to be able to understand the material provided and help other students in the group to be able also to understand the content provided by working with group members. If students want their group to be rewarded, they must help each other in the group to study the material provided. With these activities, students can be more actively involved in learning activities.

This is reinforced by the opinion of Hamdayana (2014) who stated that the STAD cooperative learning model has advantages that can make students work together in achieving goals by upholding group norms, students actively help and motivate the spirit to succeed together, proactively act as peer tutors to enhance further group success, interaction between students goes hand in hand with increasing their ability to express, improve individual skills, and strengthen group skills while Cooperative Integrated Reading and Composition (CIRC) is a learning model that has components that can make teaching and learning activities more productive and make students more creative, because here students and their groups can develop and exchange knowledge to learn a material assigned by the teacher, in addition to that, also the main activity in CIRC learning in completing problem-solving activities (Lubis C.M, 2016).

When researchers conducted a learning process using the CIRC and STAD cooperative models, several facts were found, including students who were more enthusiastic and eager to learn, especially in reading learning materials. It also makes it easier for students to remember and absorb the lesson material because the learning process occurs in groups so that they work together to work on a given task.

\section{CONCLUSIONS}

Learning outcomes in the CIRC method are better than the STAD method. This shows that there are significant differences between learning outcomes in the CIRC group and the STAD group. For this reason, it is hoped that this learning method can be applied to improve student learning outcomes and collaboration.

\section{ACKNOWLEDGMENT}

We sincerely express our most enormous gratitude to the Association of 
Indonesian Nurse Education Centers (AINEC) for funding this research.

\section{REFERENCES}

Afendi, N. (2017). Pengembangan Bahan Ajar Membaca Pemahaman Berbasis Strategi Cooperative Integrated Reading and Composition (CIRC) Sebagai Upaya Penanaman Pendidikan Karakter di Kelas VI SD. Universitas Negeri Padang.

Alligood, M. R. (2017). Nursing theory \& their work (9th ed). The CV Mosby Company St. Louis. Toronto. Missouri: Mosby Elsevier. Inc

Alsa, A. (2010). Pengaruh Metode Belajar Jigsaw Terhadap Keterampilan Hubungan Interpersonal dan Kerjasama Kelompok pada Mahasiswa Fakultas Psikologi', Jurnal Psikologi, 37(2), pp. $165-175$

Andang, et al (2017). Strategi Pembelajaran. Yogyakarta: Deepublish.

Epina, R., Manzilatusifa, U., Handoko, Sungging. (2018). Pengaruh Penggunaan Model Cooperative Learning Tipe Cooperative Integrated Reading and Composition Terhadap Peningkatan Pemahaman Konsep Peserta Didik, Educare, Vol. 16, No. 2, Des. 2018, 52-59.

Haidet, P., Kubitz, K., McCormack, W.T., (2014). Analysis of the team-based learning literature: TBL comes of age. J. Excell. Coll. Teach. 3-4 (25), 303-

Hamdayana, Jumanta. 2014. Model dan Metode Pembelajaran Kreatif dan Berkarakter. Bogor: Ghalia Indonesia

Huda, Miftahul. (2013) Model-Model Pengajaran dan Pembelajaran. Yogyakarta: Pustaka Pelajar
Huda, Miftahul. (2014). Model-model Pengajaran dan Pembelajaran Isu-Isu Metodis dan Paragmatis. Yogyakarta: Pustaka Pelajar

Jatmiko, A., Maridi (2013). The Implementation Of Cooperative Model Circ (Cooperative Integrated Reading And Composition) With Biological Comic For Increasing Students Interest In Biology Of Class Vii-A Smp Negeri 14 Surakarta Class Year 2011/2012. Pendidikan Biologi, 5(1), pp. 15-25.

Lubis, C. M., Surya, E (2016). Analisis Keefektifan Belajar Matematika Melalui Pendekatan Stop Think Do Pada Siswa Mts. Budi Agung Tahun Pelajaran 2013/2014. UNION: Jurnal Pendidikan Matematika Vol 4 No 3

Rosalina, Natalia (2016). "Pengembangan Perangkat Pembelajaran Berbasis Model Learning Cycle-7e Pada Materi Trigonometri Untuk Meningkatkan Kemampuan Koneksi Matematis Siswa". Jurnal Pendidikan: Teori, Penelitian, dan Pengembangan Volume: 1 Nomor: 6 Bulan Juni Tahun 2017.

Slavin. 2010. Cooperative Learning Teori, Riset dan Praktik. Bandung: Penerbit Nusa Media

Smith, Mary Jane; Lieher, Patricia R (2014). Middle Range Theory for Nursing. New York, NY, USA: Springer Publishing Company.

Sugiyono. (2016). Metode Penelitian

Kuantitatif, Kualitatif dan $R \& D$.

Bandung: PT Alfabet

Sutiyem. (2019). Keefektifan Model Cooperative Integrated Reading and Composition (CIRC) dalam Meningkatkan Hasil Blajar IPA Siswa Kelas VI SD Negeri 011 Air Emas. Jurnal PAJAR (Pendidikan dan Pengajaran), 3 (3), 580-586. 